\title{
REVIEW
}

\section{Treatment of oral dryness related complaints (xerostomia) in Sjögren's syndrome}

\author{
Willy A van der Reijden, Arjan Vissink, Enno C I Veerman, Arie V Nieuw Amerongen
}

Section Oral

Biochemistry,

Department of Oral

Biology, Academic

Centre for Dentistry

Amsterdam (ACTA),

Amsterdam, the

Netherlands

W A van der Reijden

E C I Veerman

A V Nieuw Amerongen

\section{Department of Oral} and Maxillofacial Surgery, University

Hospital Groningen, Groningen, the

Netherlands

A Vissink

Correspondence to:

Dr W A van der Reijden,

Section Clinical Oral

Microbiology, Department of

Oral Biology, Academic

Centre for Dentistry

Amsterdam, Van der

Boechorststraat 7, $1081 \mathrm{BT}$

Amsterdam, the Netherlands.

Accepted for publication

16 April 1999
Primary Sjögren's syndrome (SS) is a systemic autoimmune disorder characterised by a chronic, progressive loss of salivary and lacrimal function resulting in symptoms of oral and ocular dryness. The involvement of exocrine glands is the result of a focal, periductal mononuclear cell infiltrate and the subsequent loss of secretory epithelial cells. ${ }^{1}$ As a consequence, major changes occur in both the salivary flow rate and salivary composition. ${ }^{2-9}$ In the case of secondary SS a second autoimmune disease is involved, mostly rheumatoid arthritis.

The role of saliva in maintaining oral health and even quality of life is obvious in people who are lacking sufficient saliva. ${ }^{10-12}$ The effects of the reduced salivary flow rate (xerostomia) and changed salivary composition in SS are apparent (table 1): there are problems in eating, speaking, and swallowing ${ }^{12-15}$ and frequently disturbances in taste perception. ${ }^{16}$ In addition, reduced clearance of food, changes in microbial ecology and a reduced buffer capacity have their effects on oral health: an increased susceptibility to dental caries and oral infections are important clinical manifestations of the oral component of SS. ${ }^{17}$ When the systemic disease advances, salivary secretion declines further. ${ }^{7}$

A reduction of the salivary flow rate below physiological values can be induced by several other causes as well. ${ }^{19}$ Dry mouth symptoms are known as a side effect of more than 400 drugs. ${ }^{2021}$ In most of these cases the level of reduction of the salivary flow is slight and can be compensated for by mechanical or gustatory stimulation. Other common causes of prolonged hyposalivation include other autoimmune disorders such as systemic lupus erythematosus, ${ }^{22}{ }^{23}$ uncontrolled diabetes mellitus $^{24} 25$ and salivary gland injury as a result of radiotherapy in the head and neck region. ${ }^{26}$

Table 1 Consequences of xerostomia

\begin{tabular}{ll}
\hline Dryness of the mouth & Burning sensation \\
Thirst sensation & Mucus accumulation \\
Difficulties in oral functioning & Changes in soft tissues \\
Difficulties in wearing dentures & Shift in oral microbial flora \\
Nocturnal oral discomfort & Xerostomia induced caries \\
Fatigue & Taste disturbances
\end{tabular}

*A good correlation between subjective oral dryness and measured salivary flow rates is observed in about $70 \%$ of the patients. ${ }^{12}$ The other patients complain about oral dryness notwithstanding a normal salivary flow or the opposite.
This review describes the current treatments with regard to xerostomia focused on patients with SS. Because the treatment of the cause of oral dryness in Sjögren patients is possible so far, treatment is focused on stimulation of the residual capacity of the salivary glands and/or substitution of saliva with mouth rinses or saliva substitutes if stimulation of residual secretory capacity produces a too small effect. In addition, these patients need special care for preservation of their dentition and protection of their susceptible oral mucosa. With the exception of systemic treatments, there are clinically no differences in the treatment approach of the oral complaints in patients with primary and secondary SS as the choice of treatment is generally related to the level of the residual salivary secretion.

\section{Systemic treatment}

Systemic treatment of SS is generally based on treatments applied in related autoimmune diseases such as rheumatoid arthritis (RA) and systemic lupus erythematosus (SLE). In patients with secondary SS, such an approach is obvious because of the treatment of the underlying autoimmune disease. In primary Sjögren patients the use of anti-rheumatics (for example, non-steroidal anti-inflammatory drugs, NSAIDs) is to suppress inflammation.

Both prednisone and piroxicam, as examples of steroid and NSAIDs, did not significantly improve the functional or histological parameters of the salivary and lacrimal glands in SS. ${ }^{27}$ Therefore, the use of NSAIDs in SS is only indicated for the treatment of arthralgia and myalgia and for arthritis. ${ }^{28}$ Besides analgesics, other anti-rheumatics that may be useful are (hydroxy)chloroquine and methotrexate (table 2). Administration of hydroxychloroquine resulted in a significant decrease of immunoglobulin serum concentrations. ${ }^{37}$ In two small prospective trials the observed subjective improvement was not convincing, ${ }^{37} 38$ while in a larger retrospective trial by the same authors about 55 per cent of the patients noted improvement in ocular symptoms (pain and dryness). ${ }^{39}$ The same trial showed improvement of corneal integrity and lacrimal gland function in 50 per cent of the patients, improvement of subjective oral symptoms (pain and dryness) in about 60 per cent of the patients and a significantly 
Table 2 Major therapeutic agents tried for Sjögren's syndrome

\begin{tabular}{|c|c|c|c|c|}
\hline Drug & Trial design & Patients* & Results & Reference \\
\hline Cyclosporin (systemic) & open (continuation of double blind trial) & 9 primary SS & $\begin{array}{l}\text { subjective xerostomia improvement in } 88 \%(\mathrm{p}<0.01) \text {, mean } \\
\text { worsening immunopathology minor salivary glands of } 1.2 \\
\text { at a labial biopsy score from } 0-4) \text {, no effect on salivary and } \\
\text { lacrimal gland function }\end{array}$ & 29 \\
\hline $\begin{array}{l}\text { Cyclophosphamide } \\
\text { (intravenous) }\end{array}$ & case report & $\begin{array}{l}1 \text { primary SS, } \\
\text { later development } \\
\text { of polymyositis }\end{array}$ & $\begin{array}{l}\text { good response on myositis symptoms; from extensive } \\
\text { muscle fibre necrosis to type II muscle fibre atrophy. }\end{array}$ & 30 \\
\hline Azathioprine & double blind, randomised, placebo controlled & 13 primary SS & $\begin{array}{l}\text { no clinical or biochemical changes, six withdrew because of } \\
\text { side effects }\end{array}$ & 31 \\
\hline Prednisone & double blind, randomised, placebo controlled & 8 primary SS & $\begin{array}{l}\text { no objective improvement on salivary gland function; } \\
\text { subjective improvement on xerostomia and xerophthalmia }\end{array}$ & 27 \\
\hline Piroxicam & double blind, randomised, placebo controlled & 8 primary SS & no changes & 27 \\
\hline \multirow[t]{2}{*}{$\begin{array}{l}\text { Interferon } \alpha_{2}+ \\
\text { prednisone minipulse }\end{array}$} & open study $v$ hydroxychloroquine & 10 primary SS & $\begin{array}{l}\text { improvement in salivary and lacrimal function, no changes } \\
\text { in immunopathology; in three patients transient alopecia as } \\
\text { side effect }\end{array}$ & 32 \\
\hline & single blinded $v$ sucralfate & $\begin{array}{l}28 \text { primary SS }+ \\
2 \text { secondary SS }\end{array}$ & $\begin{array}{l}\text { improvement in salivary gland function in } 50 \% \text { of the } \\
\text { patients; in nine patients decrease of lymphocytic } \\
\text { infiltration in salivary glands }\end{array}$ & 33 \\
\hline Sulfasalazine & open & 10 primary SS & $\begin{array}{l}\text { improvement in two patients in arthralgia and fatigue; in } \\
\text { two patients no improvement; six patients dropped out by } \\
\text { severe side effects. }\end{array}$ & 35 \\
\hline D-penicillamine & open & 4 primary SS & $\begin{array}{l}\text { subjective improvement in saliva ( } 4 \text { patients) and tear } \\
\text { secretion ( } 2 \text { patients); side effects in two patients: pruritic } \\
\text { rash and oral ulcers, respectively. }\end{array}$ & 36 \\
\hline \multirow[t]{4}{*}{ Hydroxychloroquine } & open & 3 primary SS & $\begin{array}{l}\text { subjective improvement in saliva, tear and vaginal secretion; } \\
\text { rose bengal staining became negative in } 2 \text { patients }\end{array}$ & 37 \\
\hline & open, controlled & 10 primary SS & $\begin{array}{l}\text { decreased serum immunoglobulin levels; decreased } \\
\text { rheumatoid factor levels }\end{array}$ & 37 \\
\hline & double blinded placebo controlled crossover & 19 primary SS & $\begin{array}{l}\text { decreased serum immunoglobulin levels; no clinical } \\
\text { beneficial effects on salivary and lacrimal gland function }\end{array}$ & 38 \\
\hline & open, retrospective & 50 primary SS & $\begin{array}{l}\text { decreased IgG levels; slight improvement of oral and ocular } \\
\text { symptoms and of arthralgia/myalgia }\end{array}$ & 39 \\
\hline $\begin{array}{l}\text { Hydroxychloroquine }+ \\
\text { prednisone (mini-pulse } \\
\text { and daily } 5 \mathrm{mg} \text { ) }\end{array}$ & open $v$ interferon $\alpha_{2}$ & 10 primary SS & $\begin{array}{l}\text { no changes in serum immunoglobulin and rheumatoid factor } \\
\text { levels; no changes in salivary or lacrimal gland function }\end{array}$ & 32 \\
\hline
\end{tabular}

^Only medicated patients are listed, SS = Sjögren's syndrome.

increased salivary flow rate in 82 per cent of the patients. ${ }^{39}$ Whether the efficacy of hydroxychloroquine is related to the duration of administration needs further study, but administration of hydroxychloroquine for less than one year probably will result in less beneficial results. ${ }^{38} 39$ Moreover, the response to hydroxychloroquine of a population of patients with SS may be influenced by the diagnostic criteria that has been used to select the patients for the study. ${ }^{39}$ The "San Diego criteria" for diagnosing SS are mainly focused on the autoimmune parameters, which increase the chance of response to an immunomodulating drug when compared with patient selection on the "European criteria", which depend strongly on clinical dryness symptoms. ${ }^{40}{ }^{41}$ With respect to side effects such as retinopathy, a known adverse reaction of high dose antimalarial use, hydroxychloroquine can be used safely up to $6-7 \mathrm{mg} / \mathrm{kg} /$ day. $^{42}{ }^{43}$ In conclusion, use of hydroxychloroquine seems to be promising in the treatment of SS, although blinded, long term prospective studies are needed before this treatment can be accepted generally.

An approach to intervene in the $\mathrm{T}$ cell proliferation resulting in downregulation of interferon $\gamma$ with azathioprine was not successful. In a double blind, placebo controlled trial six of 13 patients of the treatment group withdrew because of side effects, such as nausea, anxiety and indigestion. ${ }^{31}$ One patient developed nausea and abnormal liver function and one patient withdrew because of a perforated large bowel. However, there were no distin- guishing characteristics between patients who withdrew the study and patients who completed it. Therapeutic benefit of azathioprine on symptoms, signs, serological and histological parameters was not observed. This in combination with the high incidence of adverse reactions makes azathioprine not indicated in the treatment of SS.

Another $\mathrm{T}$ cell intervening treatment is the use of low dose cyclosporin A. This agent acts by interleukin 2 inhibition and will lead to suppression of $T$ cell proliferation. In an open trial subjective xerostomia symptoms improved in $88 \%(\mathrm{p}<0.01)$ of the patients. ${ }^{29}$ However, a mean worsening immunopathology of the minor salivary glands of 1.2 (at a labial biopsy score from $0-4)$ was observed $(p<0.01)$ and there was no effect on salivary and lacrimal gland function.

Sulfasalazine has been applied to suppress hyperactive B lymphocyte activity in acute RA and primary SS. ${ }^{44}$ The clinical effects of sulfasalazine in primary Sjögren patients were disappointing: six of 10 patients stopped the study early because of side effects such as allergic reactions and agranulocytosis. Improvement of fatigue and arthralgia was observed in two patients only. It is concluded that the use of sulfasalazine in SS is not indicated. ${ }^{35}$

The use of methotrexate is indicated in patients with RA. With regard to Sjögren patients some improvement of dryness of the mouth and eyes has been reported from administration of $0.2 \mathrm{mg} / \mathrm{kg} /$ week methotrexate, but the objective parameters remained 
Table 3 Pilocarpine trials in Sjögren's syndrome for alleviating oral dryness

\begin{tabular}{|c|c|c|c|c|}
\hline Trial design & Treatment regime & Patients & Results & Reference \\
\hline $\begin{array}{l}\text { double blind, placebo } \\
\text { controlled, crossover }\end{array}$ & single dose, $5 \mathrm{mg}$ capsule & $\begin{array}{l}2 \text { primary SS }+4 \text { chronic } \\
\text { non-specific sialadenitis }\end{array}$ & $\begin{array}{l}\text { subjective dryness decreased in all patients (interview } \\
\text { score). In all patients the salivary flow was at least } \\
10 \text {-fold after pilocarpine use compared to the placebo. }\end{array}$ & 49 \\
\hline $\begin{array}{l}\text { single blind, placebo } \\
\text { controlled }\end{array}$ & $\begin{array}{l}\text { three times daily oral } \\
\text { administration of an ophthalmic } \\
2 \% \text { pilocarpine solution (eq. } 5 \mathrm{mg} \text { ) }\end{array}$ & 3 primary SS +6 secondary SS & $\begin{array}{l}\text { no changes in salivary flow in primary SS; whole } \\
\text { salivary flow increase of } 0.18 \mathrm{ml} / \mathrm{min}(\mathrm{p}<0.05) \\
\text { stimulated parotid salivary flow increase of } 0.34 \mathrm{ml} / \mathrm{min} \\
(\mathrm{p}<0.01)\end{array}$ & 52 \\
\hline $\begin{array}{l}\text { double blind, placebo } \\
\text { controlled, crossover }\end{array}$ & three times daily, $5 \mathrm{mg}$ capsule & $\begin{array}{l}18 \text { primary SS }+3 \text { secondary } \\
\text { SS }+18 \text { others with } \\
\text { hyposalivation }\end{array}$ & $\begin{array}{l}26 \text { of } 39 \text { reported an increase of parotid and } \\
\text { sublingual/submandibular saliva. Seven patients } \\
\text { withdrew from the study because of adverse effects. }\end{array}$ & 50 \\
\hline $\begin{array}{l}\text { multicentre, double } \\
\text { blind, placebo } \\
\text { controlled }\end{array}$ & unknown & $11 \mathrm{SS}^{\star}$ & $\begin{array}{l}\text { improvement in } 9 \text { patients on xerostomia and in } 8 \\
\text { patients on oral discomfort using a } 20 \text { point XOS scale. } \\
\text { Mean stimulated salivary flow rate increased about } \\
\text { threefold }(\mathrm{p}<0.08)\end{array}$ & 53 \\
\hline open & single dose, $5 \mathrm{mg}$ tablet & 9 primary SS +9 secondary SS & twofold increase of mean whole salivary output & 54 \\
\hline $\begin{array}{l}\text { double blind, placebo } \\
\text { controlled }\end{array}$ & $\begin{array}{l}5 \mathrm{mg} \text { four times daily ( } 7.5 \mathrm{mg} \text { after } \\
6 \text { weeks if tolerated by the patient) }\end{array}$ & $60 \mathrm{SS}^{\star}$ & $\begin{array}{l}64.3 \% \text { of the treatment group } v 25.0 \% \text { of the placebo } \\
\text { group indicated improvement in a global dry mouth } \\
\text { assessment on a VAS scale }(\mathrm{p}<0.005) . \text { Mean salivary flow } \\
\text { increase was } 0.14 \mathrm{ml} / \mathrm{min} v \text { zero of the placebo group. }\end{array}$ & 51 \\
\hline
\end{tabular}

^Discrimination between primary or secondary Sjögren's syndrome was not reported.

unchanged. ${ }^{34}$ As with sulfasalazine, no double blind studies have been performed to justify the use of methotrexate in SS.

Summarising, the use of systemic drugs in primary SS is not successful yet. Cyclosporin $\mathrm{A}$, azathioprine, and sulfasalazine are not indicated. More insight into the pathogenesis of primary SS is needed before new systemic treatments can be developed.

\section{Stimulation of the residual capacity of the salivary glands}

Salivary secretion is increased by non-specific mechanical and gustatory stimulants. For example, gustatory stimulation can be achieved by administration of citric acid, while chewing gum induces both mechanical and gustatory stimulation. In edentate patients acidulous stimulants can be applied ad libitum, but its use is restricted by mucosal irritation. In dry mouth patients having their own dentition, these stimulants are discouraged because the harmful effect on the teeth (demineralisation). The absence of saliva and concomitant salivary proteins and minerals makes the teeth extremely susceptible to dental erosion. Sugar free chewing gum, however, can be applied in patients with a rather high residual secretory potency of the salivary glands. In some patients, chewing gum is too sticky to dentures, although low tack chewing gums (for example, Freedent) are available. Another problem is that gustatory and mechanical stimulants only can be used during daytime as the patient has to suck or to chew. Many early Sjögren patients, however, particularly suffer from oral dryness when being at rest or during the night. This particular pattern of complaints is caused by the fact that in early Sjögren patients the salivary secretion from the mucous salivary glands (submandibular and sublingual glands), which are the major contributors to whole saliva during night time is diminished. ${ }^{5}$ When eating or being subject to any other gustatory or mechanical stimulation, the contribution of (serous) parotid saliva to whole saliva increases, resulting only a transiently reduction of a dry mouth sensation in these patients. As the disease proceeds the secretion of the parotid glands reduces as well and the effect of stimulants becomes insufficient. ${ }^{7}$ Humidification of the patient's bedroom and lubrication of the oral mucosa by a vegetable oil are widely used household medicines.

Besides oral and ocular sicca symptoms in SS, fatigue is a manifestation that affects the quality of life very seriously. It has been suggested that nocturnal oral dryness is a factor that contributes to the fatigue complaints. ${ }^{45}$ Nocturnal dryness can occur in a very early stage in SS when the submandibular glands, which are the main contributors to whole saliva during night time, are affected. In this context, studies on treatment of oral dryness in SS, reported benefits of the applied treatments during the night. ${ }^{46-48}$

Pharmacological stimulants may act throughout the day. Most studies dealing with application of pharmacological stimulants in SS have been focused on pilocarpine (for example, Salagen, Chiron, Middlesex, United Kingdom) (table 3). Pilocarpine is a muscarinergic cholinergic agonist that stimulates salivary secretion in both normal subjects and in patients suffering from impaired salivary gland function. Salivary flow rate increases within 15 minutes after oral pilocarpine administration and peak flow rates maintains for at least one hour in patients with xerostomia. ${ }^{49}$ The efficacy of pilocarpine administration, however, varies by study. Unfortunately, reports of large (multicentre) studies are lacking and study designs are sometimes unclear or incomparable by poor definition of the patient population, ${ }^{51}$ or by unusual administration forms $^{52}$ (table 3). A clinical problem of the use of pilocarpine is its broad spectrum of pharmacological (side)effects, for example, it increases secretion of all exocrine glands, including the sweat, lacrimal, gastric, pancreatic and intestinal glands, and the mucous cells of the respiratory tract. ${ }^{53}{ }^{56}$ When applied as 5 or $10 \mathrm{mg}$ tablets, three times per day, adverse effects such as sweating, chills, nausea, dizziness, rhinitis and asthenia in patients suffering from irradiation induced xerostomia or chronic graft versus host disease has been observed. ${ }^{57}$ Administration of pilocarpine in patients with primary SS showed a similar reduction of the sensation of oral dryness, but with less adverse effects. ${ }^{49} 50$ 
Because of a better peak concentration control, less side effects and a prolonged effect of pilocarpine on oral dryness probably can be expected from the use of slow release preparations. $^{5960}$

Another potential drug for treatment of xerostomia in Sjögren patients is anethole trithione. The exact mechanism of action of this drug is still unknown, but it has been reported to induce less side effects than pilocarpine. ${ }^{61}$ In Sjögren patients a beneficial effect on oral dryness has been reported by 25 mg anethole trithione, three times per day. ${ }^{62} \mathrm{~A}$ combination of pilocarpine and anethole trithione showed a synergistic effect on salivary secretion. ${ }^{63}$ Beneficial effects within the first five days of administration, were not observed in patients whose hyposalivation was attributable to anti-psychotic drug use. ${ }^{64}$

Besides pilocarpine and anethole trithione, many other drugs can stimulate the salivary glands, including carbamylcholine, yohimbine, neostigmine, and pyridostigmine, but their use is limited. In patients with a drug induced oral dryness, administration of the $\alpha_{2}$ adrenergic antagonist yohimbine resulted in more success than the use of anethole trithione. ${ }^{64}$ Besides pharmacological stimuli, acupuncture and electrostimulation have been used in the treatment of xerostomia with varying success. Both treatments seemed to be helpful for some patients, but a large individual variation in response has been reported. ${ }^{6566}$

\section{Saliva substitutes}

Replacement of saliva by a fluid other than saliva has been proposed as a possible treatment in relieving subjective complaints of xerostomia for more than three decades. Water can be used as a saliva replacement, but it is known that water does not moisten and lubricate the oral mucosa and teeth adequately. ${ }^{67}$ Therefore, saliva substitutes containing thickening agents for longer relief and increased moistening and lubrication of the oral surfaces have been developed. Particularly saliva substitutes based on carboxymethylcellulose ${ }^{68}$ or mucin ${ }^{69}$ have been applied world wide. In numerous clinical trials with different experimental designs the efficacy of carboxymethylcellulose and mucin based saliva substitutes in patients with SS have been evaluated. ${ }^{12}{ }^{46} 70-76$ Mucin preparations were also developed as a lozenge and as a chewing gum and may be used as "saliva additives". 4775 In general, most of these studies report a beneficial effect of the substitutes tested. However, there is a discrepancy between the author's opinion in review papers concerning management of xerostomia and those of original articles. Opinions about the benefit of saliva substitutes gained in patients with dry mouth in review papers are in general more reserved than the reported clinical data. ${ }^{76} 77$ Two major reasons may, at least in part, count for this discrepancy. Firstly, the efficacy of a saliva substitute is dependent on the instruction given and expectations of that patient. ${ }^{78}$ Without proper instruction, a beneficial effect of a saliva substitute is generally not to be expected. Secondly, the composition of the commercially available saliva substitutes often differs from the composition of the substitutes tested in the clinical trial. For example, the mucin ingredient in the saliva substitute Saliva Orthana was primarily a mixture of bovine submandibular mucin and porcine gastric mucin, but was changed later to porcine gastric mucin only, resulting in essentially different rheological and lubricating properties. ${ }^{677980}$

Besides saliva substitutes based on carboxymethylcellulose and animal mucins, a number of saliva substitutes based on other thickening agents have been developed such as polyethylenoxide based substitutes ${ }^{76}$ and linseed polysaccharide extracts. ${ }^{81}$ Polyethylenoxide formulations seem to give more relief in xerostomic patients than a methylcellulose based saliva substitute. ${ }^{76}$ The linseed polysaccharide based substitute has been reported to reduce the complaints of hyposalivation in about $75 \%$ of the patients. ${ }^{81}$ More recently, saliva substitutes based on polyacrylic acid and xanthan gum have been developed and evaluated in Sjögren patients. ${ }^{48}$ The latter study showed that the total population of Sjögren patients can be subdivided into subpopulations in which a particular saliva substitute is the most effective. Use of highly mucoadhesive polymers (polyacrylic acid) is recommended in saliva substitutes for patients with extremely low salivary flow rates. Patients who still are able to secrete some saliva may experience more benefit with saliva substitutes with moderate mucoadhesive and high elastic properties (xanthan gum) as these polymers can increase the "physico-chemical quality" of their residual saliva: moistening and lubrication. A similar correlation between residual salivary flow rate and efficacy of a particular saliva substitute is mentioned in the mucin containing lozenge study of 's-Gravenmade and Vissink ${ }^{47}$ and the polyglycerylmethacrylate study of Regelink and coworkers. ${ }^{82}$

\section{Treatment of oral infections}

In several studies the relation between reduction of salivary flow and increase of risk on oral infections has been demonstrated. The main oral infections observed in patients with hyposalivation are oral candidiasis, dental caries and periodontitis. ${ }^{83}$

Clinical manifestations of candidiasis have been reported to occur in up to $80 \%$ of patients with SS, mostly characterised by angular cheilitis (19-35\%) and acute erythematous candidiasis $(38-65 \%)$ rather than a whitish coat on the oral mucosa. ${ }^{84-87}$ The predominant predisposing factors of oral candidiasis in SS are the reduced salivary flow and the concomitant reduced mechanical cleansing (washing effect) of the oral surfaces. ${ }^{88}$ The removal of aggregated or adhered fungal cells is hampered, resulting in overgrowth and colonization of Candida species. ${ }^{89} 90$ The risk on development of candidiasis is higher in patients wearing removable dentures. ${ }^{91} 92$

Adequate oral hygiene is needed to prevent erythematous candidiasis and angular cheilitis. Denture wearing during the night is 
Table 4 Recommended guidelines in the prevention of xerostomia related dental decay. (Modified after Newbrun ${ }^{95}{ }^{101}$ )

1 Personal dental plaque measures

Twice daily cleaning of the teeth by use of a toothbrush (if an electric toothbrush is used, professional instruction is needed), dental floss, or interdental brush, and fluoride containing dentifrice.

2 Dietary instruction

Limit the use of between meals intake of sugary foods, candies, and sugar containing beverages. Encouraging the use of non-cariogenic sweeteners such as aspartame, saccharin, acesulfam K, sorbitol or xylitol. The last two sugars are not separately available as sweeteners.

$3 \quad$ Office fluoride therapy

At the initial visit at the dental office application of a high concentration fluoride agent, either a neutral fluoride gel for 4 minutes in a tray or a fluoride varnish directly onto the dentition. Varnishes can be applied simply by a small handbrush. As the application frequency is an important factor in determining efficacy, a four times per year application frequency is recommended.

4 Office chlorhexidine therapy (optional)

At the initial visit a $1 \%$ chlorhexidine gel for 5 minutes or a high concentration chlorhexidine varnish can be applied.

$5 \quad$ Home use fluoride therapy

A weekly to daily application of a neutral fluoride gel in a custom fitted tray. The application frequency depends on the severity of caries susceptibility. For patients who cannot tolerate a gel, a daily $0.05 \%$ sodium fluoride rinse for one minute is an alternative. The use of acidulated phosphate fluoride gels in patients with (severe) oral dryness is not recommended because of the dental erosive effects of these gels.

$6 \quad$ Home use chlorhexidine therapy (optional)

As complementing therapy, thus not as an alternative, with fluoride application chlorhexidine rinses can be used. However, the indication is limited to the number of Streptococcus mutans in saliva: $>1 \times 10^{6}$ counts $/ \mathrm{ml} \mathrm{saliva}$. If the number cultivable counts of $S$ mutans exceeds the limit $1 \times 10^{6}$ a twice daily rinse can be used during one minute for two weeks. Because of the bioavailability of fluoride in rinses, chlorhexidine should not be used simultaneously with fluoride in one solution.

discouraged. Candida species can lodge in the denture acrylate. Therefore, dentures should be cleaned with chlorhexidine solution $0.2 \%$ overnight or a chlorhexidine gel $1 \%$ two times a day in case of clinical manifestations of oral candidiasis. Oral candidiasis can be treated with topical use of miconazole gel $2 \%$, topically applied, four times per day for at least two weeks. In cases of refractory candidiasis, amphotericin B lozenges $(10 \mathrm{mg})$ can be used four times a day for at least two weeks. ${ }^{92}$ Continuous application of an anti-fungal mouthrinse to prevent oral candidiasis is still a matter of debate. Particularly formulations containing chlorhexidine or cetylpyridinium chloride might be significant, but need further study. ${ }^{93}$

In SS dental decay is a common complication that needs preventive oral care. ${ }^{94}$ It was found that in patients with SS $62 \%$ of the subjects were completely or partially edentulous (>12 teeth loss) compared with $21 \%$ in the control patient group. ${ }^{18}$ Two thirds of the Sjögren patients had lost the teeth before the age of 45 compared with $10 \%$ in the control group. This indicates that the onset of dental loss in SS may occur at an early stage, possibly related to the increased caries risk in these patients.

The mainstay of prevention against dental decay in patients with SS is through removal of dental plaque by excellent oral hygiene. The literature is, however, heterogeneous in recommendations of (preventive) treatments of dental decay in hyposalivation. The use and application time of common fluoride containing dentifrices is important, preferably with mild flavouring because of the tender oral mucous membranes. Cleansing the teeth, at least two times a day, for 5 to 10 minutes is recommended. If the patient is not able to handle a normal toothbrush, for example, for reasons of arthritis, the use of an electrical toothbrush may be helpful. Because of the tenderness of the mucous membranes, the taste of oral hygiene products can highly influence the acceptance and compliance of extensive oral care. $^{95}$

Upon progression of the hyposalivation, extensive oral hygiene including interdental cleaning and application of topical fluoride neutral gels and/or chlorhexidine gels are needed. The most suitable formulas of topical fluoride gels contain 0.4 to 1.25 per cent fluoride, have a neutral $\mathrm{pH}$ and should be used at least once a week. In cases of extreme hyposalivation the frequency of application has to be increased up to two times per day. ${ }^{96} 97$ The use of acidulated phosphate fluoride gels in patients with a (severe) dry mouth is not recommended because of the dental erosive effects of these gels and patient compliance (tenderness of the mucous membranes).

Combinations of a fluoride and chlorhexidine containing agent have proved to be highly effective in irradiated patients, and may also be suitable for patients with SS. ${ }^{98}$ This can be combined with the use of fluoride containing saliva substitutes. In vitro experiments show potential benefits of low dose fluoride intake to inhibit demineralisation (acid attacks). ${ }^{99} 100$ Table 4 summarises comprehensive recommendations of oral care in patients with SS.

Candidiasis and dental caries, are relatively simply defined because of the involvement of very few microbial species (Candida $s p p$ and Streptococcus mutans, respectively). Infection of the periodontium is more complicated by a higher number of different bacteria and also immunological as well as non-immunological factors of the host. ${ }^{102}$ Treatment of RA and SS with DMARDs or anti-inflammatory drugs may worsen the course of periodontal disease in such patients. ${ }^{103}$ Whether this is the result of the suppression of the immunological response by anti-inflammatory drugs, a reduced salivary output, or an increase of inflammatory activity in SS is still a matter of debate. ${ }^{104}$ Indeed, an odds ratio of 2.2 observed by Najera and coworkers $^{83}$ suggests a higher risk of periodontal disease in SS. However, these studies in 
which the periodontal disease has been correlated with RA or SS lack an adequate well documentation of the microbial ecology of the individual patients. Therefore, it is too preliminary to speculate about the onset of periodontitis in SS notwithstanding it is worthwhile to take into account.

\section{Future prospects}

With respect to several trials with systemic drugs in primary SS the administration of current drugs is not successful yet (table 2). Primarily, more insight in the pathogenesis is needed to develop new drugs that can modulate the hyperactivity of lymphocyte $B$ cells in those organs that are affected in SS.

At present different strategies for treatment of xerostomia in SS are being explored. In the field of pharmacological stimulation of salivary glands, slow release delivery systems for pilocarpine have been introduced. ${ }^{60} \mathrm{~A}$ significant increase in both whole and parotid salivary secretion lasting over 10 hours seems to be promising. No side effects were observed, probably because of the absence of a peak concentration directly after administration. The benefit of the pilocarpine controlled release tablet in patients with xerostomia warrants future research in a double blinded, placebo controlled study.

Development of saliva substitutes based on novel thickening agents that may provide longer retention on the mucosal surface is a subject of current interest. Two new saliva replacement products that have been shown to be effective in Sjögren patients ${ }^{48}$ are currently available in Europe, namely substitutes based on linseed polysaccharide (Salinum, Miwana $\mathrm{AB}$, Gällivare, Sweden) or xanthan gum polysaccharide (Xialine, Lommerse Pharma BV, Oss, the Netherlands). Other mucoadhesives such as carbomer (polyacrylic acid) are also potentially useful, but its application in saliva substitutes is restricted by the calcium binding properties, and thus dental demineralising properties of this polymer. ${ }^{99}$ Such substitutes, which are not on the market yet, would be applicable in edentulous patients only. A moistening mouth gel based on polyglycerylmethacrylate (Oral Balance, Laclede Inc, Gardena, CA, USA) shows moistening for more than one hour in severe xerostomic patients. ${ }^{82}$ With regard to saliva substitutes, addition of fluoride is the only confirmed caries preventive agent that is successful. ${ }^{99} 100$

A novel development is the application of natural anti-microbial compounds such as lactoperoxidase, lysozyme and lactoferrin in saliva substitutes for maintaining oral health. ${ }^{105}$ In this area, much research is aimed at the production of anti-microbial peptides, originally derived from histatins. Histatins are antifungal proteins naturally originating from the serous salivary glands, to prevent oral candidiasis. Such synthetic peptides display about 10-fold more activity against Candida albicans than natural histatins. Although these compounds have not been tested clinically, the results from in vitro studies with synthetic peptides are promising. ${ }^{106}$
A more sophisticated but also more complicated treatment is offered by gene therapy. Theoretically, the water secreting capacity of salivary glands can be increased by insertion of water transporting proteins (aquaporins) in the cell membrane of the ductal cells. Because these cells are considered to be impermeable to water, such intervention should be done to create new secretory units. From the kidney it is known that water transport is conducted by aquaporins. ${ }^{107}$ Introduction of a recombinant aquaporin in the submandibular glands of the rat by gene transfer showed a twofold increase of the saliva secretion in irradiated rats. ${ }^{108}$ If a similar mechanism is applicable in SS, it needs to be studied in a SS model because the ductal system is affected as well by the underlying disease. The susceptibility of epithelial cells to adenoviral infection is related to a distinct integrin. The integrins observed in the rat submandibular gland are also localised to the human submandibular gland. This corresponding integrin type in humans may be able to mediate the gene transfer of aquaporins to salivary glands of human patients. ${ }^{109}$ However, the main disadvantages of this technique for clinical application is its rather symptomatic and organ specific character, and, the treatment is not curing.

This last mentioned treatment is in contrast with the ongoing research in $\mathrm{T}$ cell receptor vaccination in some autoimmune diseases that may be applicable in SS. Vaccination with autoreactive $\mathrm{T}$ cells has been applied experimentally in patients with RA, ${ }^{110}$ and multiple sclerosis. ${ }^{111}$ In these studies, specific autoreactive $\mathrm{T}$ cells have been targeted with antibodies from an induced immune response against the $\mathrm{T}$ cell receptor by using whole pathogenic $\mathrm{T}$ cells. To induce a specific immune response against patient's own autoreactive $T$ cells, vaccination with these selected $\mathrm{T}$ cell clones is necessary. The results are rather promising: in a paired controlled trial the existence of myelin basic protein autoreactive $\mathrm{T}$ cells were completely depleted. ${ }^{111}$ In three of eight patients the autoreactive $\mathrm{T}$ cells reappeared with concomitant worsening of lesions or relapses.

Vaccination with $\mathrm{T}$ cell receptor peptides is another way to induce an anti-idiotypic $\mathrm{T}$ cell response by immunisation with $\mathrm{T}$ cell receptor peptides derived from the V $\beta 5.2$ gene product, the myelin basic protein $\mathrm{T}$ cell receptor sequence. ${ }^{12}$ The success rate in multiple sclerosis patients varied among patient's vaccine response. In a double blind trial only six of 15 patients with multiple sclerosis were determined as responders to V $\beta 5.2-28-58$ peptide or the 49-tyrosine-threonine substituted peptide. Clinical improvement or stability was observed in all responders. The $\mathrm{T}$ cell frequency to myelin basic protein was decreased or stable in four and two patients respectively indicating a good correlation between vaccine response and clinical outcome. ${ }^{113}$ In an uncontrolled study, decrease of activated $\mathrm{T}$ cells was observed in RA patients who were vaccinated with different doses $T$ cell receptor $V \beta 17$ peptides. ${ }^{14}$ Concomitantly, a decrease of lymphocyte proliferation was observed in about 40 
per cent of the patients. Finally, the mean painful joint score has been improved significantly. The association between vaccination response, reduction of lymphocyte proliferation and clinical benefit in $\mathrm{T}$ cell (peptide) vaccination suggests a very promising step forward to treatment of autoimmune diseases such as multiple sclerosis and RA, notwithstanding the number of responding patients, which is below 50 per cent. Intensifying of the research in this field is definitely worthwhile because of its curing character.

\section{Conclusions}

The oral component is a main symptom in SS. ${ }^{115}$ However, the pathogenesis is not understood yet, and more research is needed to develop effective systemic treatments, both curative and symptomatic. The treatment to relieve dryness related symptoms is mainly based on stimulation of the residual secretory capacity of the affected salivary glands and, if this is no longer successful, replacement of natural saliva with a saliva substitute. Worthwhile saliva substitutes contain a thickening agent to provide longer retention on the oral mucosa and biologically active compounds for the prevention of dental decay and (fungal) opportunistic infections. Such additions may support the optimal oral care that is a sine qua non. New prospects are incorporation of antimicrobial compounds in saliva substitutes and mouth gels, and the ongoing research in gene therapy by integration of water channels into the ductal cells of the salivary glands to increase the secretory potency of these glands. Immunomodulation using vaccination with attenuated $\mathrm{T}$ cells or $\mathrm{T}$ cell receptor epitopes has not been proved successful in a $100 \%$ of the patients with multiple sclerosis or RA tested but it will be the new challenge for treating autoimmune diseases.

1 Fox PC, Speight PM. Current concepts of autoimmune exocrinopathy: Immunologic mechanisms in the salivary pathology of Sjögren's syndrome. Crit Rev Oral Biol Med pathology of Sj:

2 Daniels TE, Silverman Jr S, Michalski JP, Greenspan JS, Path MRC, Sylvester RA, et al. The oral component of Sjögren's syndrome. Oral Surg 1975;39:875-85

Mandel ID, Baurmash H. Sialochemistry in Sjögren's syndrome. Oral Surg 1976;41:182-7.

4 Fox PC, Sarras AK, Bowers MR, Drosos AA, Moutsopoulos $\mathrm{HM}$. Oral and sialochemical findings in patients with autoimmune rheumatic disease. Clin Exp Rheumatol 1987;5:123-6.

5 Atkinson JC, Travis WD, Pillemer SR, Bermudez D, Wolff A, Fox PC. Major salivary gland function in primary Sjögren's syndrome and its relationship to clinical features. J Rheumatol 1990;17:318-22.

6 Speight PM, Kaul A, Melsom RD. Measurement of whole unstimulated salivary flow in the diagnosis of Siögren's unstimulated salivary flow in the diagnosis
syndrome. Ann Rheum Dis 1992;51:499-502

7 Vissink A, Panders AK, Nauta JM, Ligeon EE, Nikkels PGJ Kallenberg CGM. Applicability of saliva as a diagnostic fluid in Sjögren's syndrome. Ann N Y Acad Sci 1993;694: $325-9$

8 Vitali C, Moutsopoulos HM, Bombardieri S and The European Community Study Group on Diagnostic Criteria for Sjögren's Syndrome. The European Community diagnostic criteria for Sjögren's Syndrome Sensitivity and specificity of tests for ocular and oral involvement in Sjögren's syndrome. Ann Rheum Dis 1994;53:637-47.

9 Van der Reijden WA, Van der Kwaak JS, Veerman ECI Nieuw Amerongen AV. Analysis of the concentration and output of whole salivary constituents in patients with Sjögren's syndrome. Eur J Oral Sci 1996;104:335-40.

10 Mandel ID. The role of saliva in maintaining oral homeostasis. J Am Dent Assoc 1989;119:298-304.

11 Fox PC, Van der Ven PF, Sonies BC, Weiffenbach JM, Baum BJ. Xerostomia: evaluation of a symptom with increasing significance. J Am Dent Assoc 1985;110:519 25 .
12 Vissink A, Schaub RMH, Van Rijn LJ, 's-Gravenmade EJ, Panders AK, Vermey A. The efficacy of mucin-containing artificial saliva in alleviating symptoms of xerostomia. Gerodontol 1987;6:95-101

13 Sreebny LM. Salivary flow in health and disease. Compendium 1989;13 (suppl):S461-9.

14 Rhodus NL, Moller K, Colby S, Bereuter J. Dysphagia in patients with three different etiologies of salivary gland dysfunction. Ear Nose Throat J 1995;74:39-48.

15 Soto-Rojas AE, Villa AR, Sifuentes-Osornio J, AlarcónSegovia D, Kraus A. Oral manifestations in patients with Sjögren's syndrome. J Rheumatol 1998;25:906-10.

16 Weiffenbach JM, Schwartz LK, Atkinson JC, Fox PC. Taste performance in Sjögren's syndrome. Physiol Behav 1995; 57:89-96.

17 Jorge AOC, Totti MAG, Almeida OP de, Scully C. Ora candidiasis established in the sialoadenectomised rat. J Oral Pathol Med 1993;22:54-6.

18 Baudet-Pommel M, Albuisson E, Kemeny JL, Falvard F, Ristori JM, Fraysse MP, et al. Early dental loss in Sjögren's syndrome - Histologic correlates. Oral Surg Oral Med Oral Pyndrome - Histologic con

19 Field EA, Longman LP, Bucknall R, Kaye SB, Higham SM, Edgar WM. The establishment of a xerostomia clinic: a prospective study. Br J Oral Maxillofac Surg 1997;35:96103.

20 Sreebny LM, Schwartz SS. A reference guide to drugs and dry mouth. Gerodontol 1986;5:75-99.

21 Zelickson BD, Rogers RS III. Drug reactions involving the mouth. Clin Dermatol 1986;4:98-109.

22 Ben-Aryeh H, Gordon N, Szargel R, Toubi E, Laufer D. Whole saliva in systemic lupus erythematosus patients. Oral Surg Oral Med Oral Pathol 1993;75:696-9.

23 Sullivan DA. Sex hormones and Sjögren's syndrome. J Rheumatol 1997;24:17-32.

24 Cherry-Peppers G, Sorkin J, Andres R, Baum BJ, Ship JA Salivary gland function and glucose metabolic status. J Gerontol 1992;47:M130-4

25 Sreebny LM, Yu A, Green A, Valdini A. Xerostomia in diabetes mellitus. Diabetes Care 1992;15:900-4.

26 Valdez IH, Atkinson JC, Ship JA, Fox PC. Major salivary gland function in patients with radiation-induced xerostomia: flow rates and sialochemistry. Int J Rad Oncol Biol Phys 1993;25:41-7.

27 Fox PC, Datiles M, Atkinson JC, Macynski AA, Scott J, Fletcher D, et al. Prednisone and piroxicam for treatment of primary Sjögren's syndrome. Clin Exp Rheumatol 1993; 11:149-56.

28 Fox RI. Treatment of the patient with Sjögren's syndrome. Rheum Dis Clin North Am 1992;18:699-709.

29 Drosos AA, Skopouli FN, Galanapoulou VK, Kitridou RC, Moutsopoulos HM. Cyclosporin A therapy in patients with primary Sjögren's syndrome: results after one year. Scand J Rheumatol 1986;61 (suppl):246-9.

30 Leroy JP, Drosos AA, Yiannopoulos DI, Youinou P, Moutsopoulos HM. Intravenous pulse cyclophosphamide therapy in myositis and Sjögren's syndrome. Arthritis therapy in myositis and

31 Price EJ, Rigby SP, Clancy U, Venables PJW. A double blind placebo controlled trial of azathioprine in the treatment of primary Sjögren's syndrome. J Rheumatol 1998;25:896-9.

32 Ferraccioli GF, Salaffi F, De Vita S, Casatta L, Avellini C, Carotti $M$, et al. Interferon alpha-2 (IFN 2 2) increases lacrimal and salivary function in Sjögren's syndrome patients. Preliminary results of an open trial versus $\mathrm{OH}-$ chloroquine. Clin Exp Rheumatol 1996;14:367-71.

33 Shiozawa S, Tanaka Y, Shiozawa K. Single-blinded controlled trial of low-dose oral IFN-alpha for the treatment of xerostomia in patients with Sjögren's syndrome. J Interferon Cytokine Res 1998;18:255-62.

34 Skopouli FN, Jagiello P, Tsifetaki N, Moutsopoulos HM. Methotrexate in primary Sjögren's syndrome. Clin Exp Rheumatol 1996,14:555-8.

35 Kruize AA, Hené RJ, Vianen ME, Lafeber FPJG, Kater L, Bijlsma JWJ. Systemic treatment of patients with primary Sjögren's syndrome: not with sulfasalazine. In: Kruize AA Clinical and experimental studies on Sjögren's syndrome. [Thesis]. Utrecht: Universiteit Utrecht, 1997:81-92.

36 Lakhanpal S, Duffy J, Griffing WL, Conn DL, Luthra HS Sjögren's syndrome: treatment with D-penicillamine and hydroxychloroquine. J Rheumatol 1985;12:1028-9.

37 Fox RI, Chan E, Benton L, Fong S, Friedlaender M, Howell FV. Treatment of primary Sjögren's syndrome with hydroxychloroquine. Am J Med 1988;85 (suppl 4A):62-7.

38 Kruize AA, Hené RJ, Kallenberg CGM, van Bijsterveld OP Kruize AA, Hene RJ, Kallenberg CGM, van Bijsterveld OP,
van der Heijde A, Kater L, et al. Hydroxychloroquine treatvan der Heijde A, Kater L, et al. Hydroxychloroquine treatment for primary Sjögren's syndrome: a two year doub
blind crossover trial. Ann Rheum Dis 1993;52:360-4.

39 Fox RI, Dixon R, Guarrasi V, Krubel S. Treatment of primary Sjögren's syndrome with hydroxychloroquine: a retrospective open-label study. Lupus 1996;5 (supp 1):S31-6.

40 Fox RI, Saito I. Criteria for diagnosis of Sjögren's syndrome. Rheum Dis Clin North Am 1993;20:391.

41 Vitali C, Bombardieri S, Moutsopoulos HM, Balestrieri G, Bencivelli W, Bernstein RM, et al. Preliminary criteria for the classification of Sjögren's syndrome - Results of a prothe classification of Sjogren's syndrome - Results of a prospective concerted action supported by the

42 Levy GD, Munz SJ, Paschal J, Cohen HB, Pince KJ, Peterson $\mathrm{T}$. Incidence of hydroxychloroquine retinopathy in 1,207 patients in a large multicenter outpatient practice Arthritis Rheum 1997;40:1482-6. 
43 Albert DA, Debois LKL, Lu KF. Antimalarial ocular toxicity - a critical appraisal. J Clin Rheumatol 1998;4:57-62

44 Imai F, Suzuki T, Ishibashi T, Tanaka M, Akiyama Y, Doh $Y$. Effect of sulfasalazine on B cell hyperactivity in patient with rheumatoid arthritis. J Rheumatol 1994;20:612-15.

45 Gudbjörnsson B, Broman JE, Hetta J, Hällgren R. Sleep disturbances in patients with primary Sjögren's syndrome. Br J Rheumatol 1993;32:1072-6.

46 Klestov AC, Webb J, Latt D, Schiller G, McNamara K, Young DY, et al. Treatment of xerostomia: A double-blind trial in 108 patients with Sjögren's syndrome. Oral Surg Oral Med Oral Pathol 1981;51:594-9.

$47 \mathrm{~s}-$ Gravenmade EJ, Vissink A. Mucin-containing lozenges in the treatment of intraoral problems associated with Sjögren's syndrome - A double-blind crossover study in 42 patients. Oral Surg Oral Med Oral Pathol 1993;75:466-71.

48 Van der Reijden WA, Van der Kwaak H, Vissink A, Veerman ECI, Nieuw Amerongen AV. Treatment of xerostomia with polymer-based saliva substitutes in patients with Sjögren's syndrome. Arthritis Rheum 1996;39:57-69.

49 Fox PC, Van der Ven PF, Baum BJ, Mandel ID. Pilocarpine for the treatment of xerostomia associated with salivary gland dysfunction. Oral Surg Oral Med Oral Pathol 1986; 61:243-5.

50 Fox PC, Atkinson JC, Macynski AA, Wolff A, Kung DS, Valdez $\mathrm{IH}$, et al. Pilocarpine treatment of salivary gland hypofunction (xerostomia) and dry mouth. Arch Intern Med 1991;151:1149-52.

51 Papas AS, Fernandez MM, Castano RA, Gallagher SC, Trivedi M, Shrotriya RC. Oral pilocarpine for symptomatic
relief of dry mouth and dry eyes in patients with Sjögren's relief of dry mouth and dry eyes in patients with
syndrome. Arch Exp Med Biol 1998;438:973-8

52 Rhodus NL, Schuh MJ. Effects of pilocarpine on salivary flow in patients with Sjögren's syndrome. Oral Surg Ora Med Oral Pathol 1991;72:545-9.

53 Vivino FB, Hermann GA, Huang CH, Katz WA. Preliminary study of pilocarpine tablets in Sjögren's syndrome. [Abstract]. Arthritis Rheum 1994;37 (suppl):S208.

54 Rhodus NL. Oral pilocarpine $\mathrm{HCl}$ stimulates labial (minor) salivary gland flow in patients with Sjögren's syndrome. Oral Dis 1997;3:93-8

55 Yanaura S, Takeda H, Nishimura T, Misawa M. Effect of pilocarpine on behavior of mucus glycoproteins of canine
tracheal secretory cells. Jpn J Physiol 1982;32:29-35.

56 Wiseman LR, Faulds D. Oral pilocarpine: A review of its pharmacological properties and clinical potential in xerostomia. Drugs 1995;1:143-55.

57 Johnson JT, Ferretti GA, Nethery WJ, Valdez IH, Fox PC, $\mathrm{Ng} \mathrm{D}$, et al. Oral pilocarpine for post-irradiation xerostomia in patients with head and neck cancer. N Engl J Med 1993; 329:390-5.

58 Singhal S, Mehta J, Rattenbury H, Treleaven J, Powles R. Oral pilocarpine hydrochloride for the treatment of refractory xerostomia associated with chronic graft-versus-host tory xerostomia associated with

59 Zimmer AK, Chetoni P, Saettone MF, Zerbe H, Kreuter J. Evaluation of pilocarpine-loaded albumin particles as controlled drug delivery systems for the eye. II Cotrolled drug delivery systems for the eye. II Coadministration with bioadhesive and viscou

60 Lockhart PB, Fox PC, Gentry AC, Acharya R, Norton HJ. Pilot study of controlled-release pilocarpine in normal subjects. Oral Surg Oral Med Oral Pathol Oral Radiol Endod 1996;82:517-24.

61 Glenert U. Effects of chronic anethole trithione and amitriptyline treatment on rat parotid gland signalling. Eu J Pharmacol - Mol Pharmacol Section 1992;226:43-52.

62 Epstein JB, Decoteau WE, Wilkinson A. Effect of Sialor in treatment of xerostomia and in Sjögren's syndrome. Oral Surg Oral Med Oral Pathol 1983;56:495-9.

63 Epstein JB, Schubert MM. Synergistic effect of sialogogues in management of xerostomia after radiation therapy. Oral in management of xerostomia after radiation

64 Bagheri H, Schmitt L, Berlan M, Montastruc JL. A comparative study of the effects of yohimbine and anethol trithione on salivary secretion in depressed patients treated with psychotropic drugs. Eur J Clin Pharmacol 1997;52: 339-42.

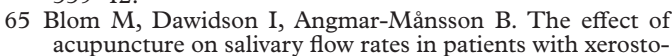
mia. Oral Surg Oral Med Oral Pathol 1992;73:293-8.

66 Talal N, Quinn JH, Daniels TE. The clinical effects of electrostimulation on salivary function of Sjögren's syndrome patients. Rheumatol Int 1992;12:43-5.

67 Vissink A, de Jong HP, Busscher HJ, Arends J, 'sGravenmade EJ. Wetting properties of human saliva and Gravenmade EJ. Wetting properties of human
saliva substitutes. J Dent Res 1986;65:1121-4.

68 Matzker J, Schreiber J. Synthetischer Speichel zur Therapie der Hyposalien, insbesondere bei der radiogenen Sialadenitis. Z Laryng Rhinol Otol 1972;51:422-8.

69 s-Gravenmade EJ, Roukema PA, Panders AK. The effect of mucin-containing artificial saliva on severe xerostomia. In J Oral Surg 1974;3:435-9.

70 Weisz AS. The use of a saliva substitute as treatment for xerostomia in Sjögren's syndrome - A case report. Ora Surg Oral Med Oral Pathol 1981;52:384-6.

71 Donatzky O, Johnsen T, Holmstrup P, Bertram U. Effect of Saliment on parotid salivary gland secretion and on xerostomia caused by Siögren's syndrome. Scand J Dent Res 1982;90:157-62.

72 Vissink A, 's-Gravenmade EJ, Panders AK, Vermey A, Petersen JK, Visch LL. A clinical comparison between commercially available mucin- and CMC-containing saliva substitutes. Int J Oral Surg 1983;12:232-8.
73 Visch LL,'s-Gravenmade EJ, Schaub RMH, Van Putten WLJ, Vissink A. A double-blind crossover trial of CMCand mucin-containing saliva substitutes. Int $\mathrm{J}$ Oral Maxillofac Surg 1986;15:395-400.

74 Duxbury AJ, Thakker NS, Wastell DG. A double blind cross-over trial of a mucin-containing artificial saliva. $\mathrm{Br}$ Dent J 1989;166:115-20.

75 Aagaard A, Godiksen S, Teglers PT, Schiødt M, Glenert U. Comparison between new saliva stimulants in patients with dry mouth: a placebo-controlled double-blind crossover study. J Oral Pathol Med 1992;21:376-80.

76 Marks NJ, Roberts BJ. A proposed new method for the treatment of dry mouth. Ann R Coll Surg Engl 1983;65: $191-3$.

77 Atkinson JC, Wu AJ. Salivary gland dysfunction: causes, symptoms, treatment. J Am Dent Assoc 1994;125:409-16.

78 s-Gravenmade EJ, Vissink A. Management of the oral 24

79 Mellema J, Holterman HJ, Waterman HA, Blom C, 's-Gravenmade EJ. Rheological aspects of mucincontaining solutions and saliva substitutes. Biorheology 1992;29:231-49.

80 Van der Reijden WA, Veerman ECI, Nieuw Amerongen AV. Rheological properties of commercially available polysaccharides with potential use in saliva substitutes. Biorheology 1994;31:631-42.

81 Johansson G, Andersson G, Attström R, Glantz PO, Larsson K. The effect of Salinum on the symptoms of dry mouth: a pilot study. Gerodontol 1994;11:46-9.

82 Regelink G, Vissink A, Reintsema H, Nauta JM. Efficacy of of a synthetic polymer saliva substitute in reducing oral complaints of patients suffering from irradiation-induced complaints of patients suffering from irradiation-induced

83 Najera MP, Al-Hashimi I, Plemons JM, Rivera-Hidalgo F Rees TD, Haghighat N, et al. Prevalence of periodontal disease in patients with Sjögren's syndrome. Oral Surg Ora Med Oral Pathol Oral Radiol Endod 1997;83:453-7.

84 Tapper-Jones L, Aldred M, Walker DM. Prevalence and intraoral distribution of Candida albicans in Sjogren's syndrome. J Clin Pathol 1980;33:282-7.

85 Lundström IMC, Lindström FD. Subjective and clinical oral symptoms in patients with primary Sjögren's syndrome. Clin Exp Rheumatol 1995; 13:725-31.

86 Rhodus NL, Bloomquist C, Liljemark W, Bereuter J. Prevalence, density, and manifestations of oral Candida albicans
in patients with Sjögren's syndrome. J Otolaryngol in patients w.

87 Soto-Rojas AE, Villa AR, Sifuentes-Osornio J, AlarcónSegovia D, Kraus A. Oral candidiasis and Sjögren's syndrome. J Rheumatol 1998;25:911-15.

88 Challacombe S. Immunology of oral candidosis. In Samaranayake LP, MacFarlane TW, eds. Oral candidosis. London: Butterworth, 1990:104-23.

89 MacFarlane TW. Ecology and epidemiology of Candida. In: Samaranayake LP, MacFarlane TW, eds. Oral candidosis. London: Butterworth, 1990:21-46.

90 Holmes AR, Cannon RD, Jenkinson HF Interaction of Candida albicans with bacteria and salivary molecules in oral biofilms. Journal of Industrial Microbiology 1995; 15: 208-13.

91 Budtz-Jörgensen E. The signficance of Candida albicans in denture stomatitis. Scand J Dent Res 1974;82:151-90.

92 Budtz-Jörgensen E, Lombardi T. Antifungal therapy in the oral cavity. Periodont 2000 1996;10:89-106.

93 Giuliana G, Pizzo G, Milici ME, Musotto GC, Giangreco $R$. In vitro antifungal properties of mouthrinses containing antimicrobial agents. J Periodontol 1997;68:729-33.

94 Papas AS, Joshi A, MacDonald SL, Maravelis-Splagounias L, Pretara-Spanedda P, Curro FA. Caries prevalence in L, Pretara-Spanedda P, Curro FA. Caries prevalence in

95 Newbrun E. Current treatment modalities of oral problems of patients with Sjögren's syndrome: caries prevention. Adv Dent Res 1996;10:9-34.

96 Jansma J, Vissink A, 's-Gravenmade EJ, Visch LL, Fidler V, Retief DH. In vivo study on the prevention of postradiation caries. Caries Res 1989;23:172-8.

97 Spak CJ, Johnson G, Ekstrand J. Caries incidence salivary flow rate and efficacy of fluoride gel treatment in irradiated patients. Caries Res 1994;28:388-93.

98 Joyston-Bechal S, Hayes K, Davenport ES, Hardie JM. Caries incidence, mutans streptococci and lactobacilli in irradiated patients during a 12 -month preventive programme using chlorhexidine and fluoride. Caries Res 1992;26:384-90.

99 Van der Reijden WA, Buijs MJ, Damen JJM, Veerman ECI, Ten Cate JM, Nieuw Amerongen AV. Influence of polymers for use in saliva substitutes on de- and remineralization of enamel in vitro. Caries Res 1997;31:216-23.

100 Shannon IL, Trodahl JN, Starcke EN. Remineralization of enamel by a saliva substitute designed for use by irradiated patients. Cancer 1978;41:1746-50.

101 Council on Acces, Prevention and Interprofessional Relations. Caries diagnosis and risk assessment: a review of preventive strategies and management. J Am Dent Assoc 1995;126 (special suppl): 1-24S.

102 Page RC, Offenbacher S, Schroeder HE, Seymour GJ, Kornman KS. Advances in the pathogenesis of periodontitis: summary of developments, clinical implicaperiodontitis: summary of developments, clinical implica-
tions and future directions. Periodont 2000 1997;14:216tions

103 Käßer UR, Gleissner C, Dehne F, Michel A Willershausen-Zönnchen B, Bolten WW. Risk for peri- 
odontal disease in patients with longstanding rheumatoid arthritis. Arthritis Rheum 1997;40:2248-51.

104 Deodhar AA, Bennett RM. Periodontal health in patients with rheumatoid arthritis: comment on the article of Käßer et al. Arthritis Rheum 1998;41:2081-2.

105 Kirstilä V, Lenanderlumikari M, Söderling E, Tenovuo J. Effects of oral hygiene products containing lactoperoxidase, lysozyme, and lactoferrin on the composition of whole saliva and on subjective oral symptoms in patients with xerostomia. Acta Odontol Scand 1996;54:391-7.

106 Helmerhorst EJ, Van't Hof W, Veerman ECI, SimoonsSmit I, Nieuw Amerongen AV. Synthetic histatin analogues with broad-spectrum antimicrobial activity. Biochem J 1997;326:39-45.

107 Knepper MA. The aquaporin family of molecular water channels. Proc Natl Acad Sci USA 1994;91:6255-8.

108 Delporte C, O'Connell BC, He X, Lancaster HE, O'Connell AC, Agre P, et al. Increased fluid secretion after adenoviral-mediated transfer of the aquaporin-1 cDNA to irradiated rat salivary glands. Proc Nat Acad Sci USA 1997;94:3268-73.

109 Delporte C, Redman RS, Baum BJ. Relationship between the cellular distribution of the $\alpha_{4} \beta_{35}$ integrin and adenoviral infection in salivary glands. Lab Invest 1997;77:167-73.
110 Van Laar JM, De Vries RR, Breedveld FC. T-cell vaccination in humans: the experience in rheumatoid arthritis. Clin Exp Rheumatol 1993;11(suppl 8):S59-62.

111 Medaer R, Stinissen P, Truyen L, Raus J, Zhang J. Depletion of myelin-basic-protein autoreactive $\mathrm{T}$ cells by T-cell vaccination: pilot trial in multiple sclerosis. Lancet 1995;346:807-8.

112 Bourdette DN, Whitham RH, Chou YK, Morrison WJ, Atherton J, Kenny C, et al. Immunity to TCR peptides in multiple sclerosis. I Successful immunization of patients with synthetic V $\beta 5.2$ and V 36.1 CDR2 peptides. J Immunol 1994;152:2510-19.

113 Vandenbark AA, Chou YK, Whitham R, Mass M, Buenafe A, Liefield D, et al. Treatment of multiple sclerosis with T-cell receptor peptides: Results of a double-blind pilot trial. Nature Medicine 1996;2:1109-15.

114 Moreland LW, Heck LW, Koopman WJ, Saway PA, Adamson TC, Fronek Z, et al. V $\beta 17$ T cell receptor peptide vaccination in rheumatoid arthritis: results of phase I dose escalation study. J Rheumatol 1996;23:1353-62.

115 Manthorpe R, Kirtava Z, Jacobsson L, Tabery H, Henricsson V, Axéll T, et al. Main subjective symptoms in 217 patients with primary Sjögren's syndrome (pSS) - results from Malmö. J Clin Rheumatol 1995;14 (suppl 1):50.

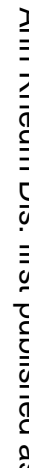

